\title{
Cytoskeleton Structure in Mouse Sperm and Testes After 30 Days of Hindlimb Unloading and 12 Hours of Recovery
}

\author{
Maria A. Usik ${ }^{a, b} \quad$ Irina V. Ogneva $a^{a, b}$ \\ ${ }^{a}$ Cell Biophysics Laboratory, State Scientific Center of Russian Federation Institute of Biomedical \\ Problems of the Russian Academy of Sciences, Moscow, ㅁ.M. Sechenov First Moscow State Medical \\ University, Moscow, Russia
}

\section{Key Words}

Weightlessness $\bullet$ Cytoskeleton $\bullet$ Sperm $・$ Testes $\bullet$ Sperm-specific proteins

\begin{abstract}
Background/Aims: Changes in the external mechanical field result in cytoskeleton reorganization and the formation of adaptive patterns in different types of cells, including somatic cells and sex cells. The aim of this research was to study the protein and mRNA content of cytoskeletal and sperm-specific genes in the sperm and testis cells of mice. Methods: Mice were subjected to 30 days of antiorthostatic suspension to simulate weightlessness, followed by $12 \mathrm{~h}$ of recovery, while receiving essential phospholipids at a dosage of $500 \mathrm{mg} / \mathrm{kg} / \mathrm{day}$ ( $30 \mathrm{HSE}$ and $30 \mathrm{HSE}+12 \mathrm{~h}$ groups) or a similar dosage of a placebo (30HS and $30 \mathrm{HS}+12 \mathrm{~h}$ groups). Accordingly, reference groups (CE group and C group) were formed. The total number and the percentage of motile spermatozoa were calculated using a Makler chamber. To analyze the number of viable spermatozoa and the permeability of their membranes, eosin staining was used as well as Diff-Quick for a morphological evaluation. Relative protein and mRNA content was estimated in a western blot and quantitative PCR assay, respectively. Results: The relative protein expression levels of actin (beta and gamma) and two alpha-actinin isoforms (1 and 4) remained constant in the sperm of all study groups, except for the $30 \mathrm{HS}+12 \mathrm{~h}$ group, where the alpha-actinin-4 level was $13 \%$ higher than in the reference group $(p<0.1)$. In the testis cells, the relative actin isoform content was equivalent to that in the spermatozoa. However, in the testis cells, the ACTN1 mRNA content was $17 \%$ higher in the $30 \mathrm{HS}$ group than in the $C$ group $(p<0.05)$, and decreased after $12 \mathrm{~h}$ of recovery. In contrast, the ACTN4 mRNA content was $20 \%$ lower in the 30HS group than in the reference group $(p<0.05)$ and increased after the 12-h recovery period. At the same time, in the group administered the essential phospholipids, the relative ACTN1 and ACTN4 mRNA content did not differ from those of the reference group. The relative beta-tubulin content was similar in the reference $C$ group and the reference $C E$ group, which was administered the essential phospholipids. In the $30 \mathrm{HS}$ and $30 \mathrm{HS}+12 \mathrm{~h}$ groups, the beta-tubulin content decreased by $19 \%$ and $22 \%(\mathrm{p}<0.05)$,

\footnotetext{
Dr. Irina V. Ogneva Cell Biophysics Laboratory, State Scientific Center of Russian Federation Institute of Biomedical Problems of the Russian Academy of Sciences, I.M. Sechenov First Moscow State Medical University Moscow (Russia); Tel. +74991956398, Fax +74991952253, E-Mail iogneva@yandex.ru
} 


\section{Cellular Physiology \\ \begin{tabular}{ll|l} 
and Biochemistry & $\begin{array}{l}\text { DOI: 10.1159/000495235 } \\
\text { Published online: } 17 \text { November } 2018\end{array}$ & $\begin{array}{l}\text { @ } 2018 \text { The Author(s). Published by S. Karger AG, Basel } \\
\text { www.karger.com/cpb }\end{array}$ \\
\hline Usik et al: Cytoskeleton Structure in Mouse Sperm and Testes in Modeled Microgravity
\end{tabular}}

respectively, and they also decreased in the groups administered the essential phospholipids (30HSE and $30 \mathrm{HSE}+12 \mathrm{~h}$ groups, by $27 \%$ and $33 \%$, respectively, $\mathrm{p}<0.05)$. In the testis tissue, the relative tubulin content did not change in any of the experimental groups. At the same time, the relative mRNA content of the genes encoding the studied cytoskeletal proteins increased, which may indicate the protein content was regulated mainly at the translational level. Conclusion: The spermogram parameters and the content of the sperm-specific proteins and the associated mRNAs revealed a decrease in the number of mature spermatozoa in mice suspended under conditions of weightlessness. Moreover, the decrease was prevented by the administration of essential phospholipids.

(C) 2018 The Author(s)

Published by S. Karger AG, Basel

\section{Introduction}

The exploration of outer space is hampered not only by technical difficulties, but also by a number of medical problems, especially those associated with the negative effects of weightlessness, including issues at the cellular level. Nevertheless, the mechanisms underlying the interactions of a living cell with the physical field remain unclear.

In various types of cells that were cultured under the conditions of altered gravity, there are changes in the cellular profiles, disorganization of the microfilaments and sometimes the microtubules [1-6], and changes in the localization of the mitochondria [7], which is determined by the state of the intermediate filaments. In addition, changes have been reported in the expression levels of genes encoding cytoskeletal proteins and their associated signaling cascade participants [8-14]. Moreover, when the effects of microgravity are simulated in mesenchymal stem cells, osteogenic differentiation is inhibited, and adipogenic differentiation is activated [9-15], inhibiting the ability of embryonic stem cells to form embryoid bodies $[16,17]$. Similar changes in the differentiation potential of stem cells under conditions of altered gravity may be associated with the reorganization of the cytoskeleton because its structures may participate in the selection of differentiation routes $[18,19]$. Consequently, it can be assumed that the early stages of embryogenesis and gametogenesis, particularly in mammals, may be especially dependent on external mechanical conditions.

Pregnant rats spent 5 days aboard the Soviet satellites Kosmos-1129 (1979) and Kosmos-1514 (1983), and 11 days aboard the Space Shuttle during the second half of pregnancy in a joint experiment by Russian and American researchers (NIH-R1) (1994). Anatomical changes were not detected in any of these experiments, but the flight group animals exhibited accelerated development of the thyroid and parathyroid glands, decreases in mitotic activity and the number of cells in the thymus, and changes in the nervous system compared with control group animals on the ground [20-23]. It should be noted that rats are amniotic, and hence the development of embryos during the second half of pregnancy occurs in amniotic fluid, which can successfully dampen the changes in the external mechanical field. Additionally, the observed changes were associated with a change in the hormonal status of the females under the condition of weightlessness. When studying the early stages of development under the condition of weightlessness, mice were unable to become pregnant because pre-implanted embryos were aborted [24], possibly because of a change in the structure of the sex cells.

Space flight conditions decrease the number of mature spermatozoa in the testes of rats [25-27], indicating that the differentiation potential of precursor cells is changed, which decreases the efficiency of spermatogenesis [28]. Nevertheless, microgravity activates the cyclinB-cdc2 complex and the subsequent meiotic progression of isolated mouse spermatocytes from the mid-pachytene stage to the late-pachytene stage [29]. In sea urchin spermatozoa subjected to space flight conditions (STS-81, STS-84), phosphorylation of the FP130 protein, which is associated with the activation of mobility, occurs 3-4 times faster than under the condition of $1 \mathrm{~g}$ [30]. 


\section{\begin{tabular}{ll} 
Cellular Physiology & Cell Physiol Biochem 2018;51:375-392 \\
\hline DOl: 10.1159/000495235 & O 2018 The Author(s). Published by 5. Karger AG, Basel
\end{tabular}

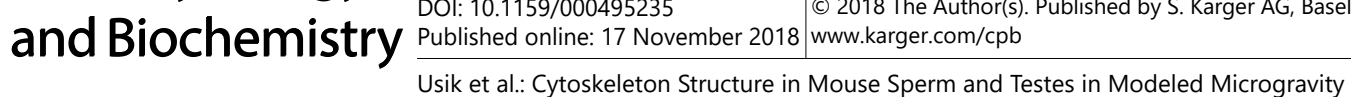

The published data indicate that changes in gravity have significant effects on the structure of cells and the pattern of gene expression, with similar changes observed for cells in culture and in tissue. The results of our previous studies revealed the formation of an adaptive pattern of cytoskeletal proteins in the muscle cells of rats and mice under the conditions of real space flight, modeled microgravity, and hypergravity [31-35]. Moreover, we have successfully used lecithin to prevent some changes in the structure of the cytoskeleton of muscle cells in rats undergoing antiorthostatic suspension [36].

At the same time, data on changes in male sex cells under microgravity conditions are very scarce. Therefore, we decided to evaluate the structure of the cytoskeleton of spermatozoa and, more generally, the testis cells of mice subjected to conditions simulating the effects of microgravity for a prolonged period. Mice were orally administered essential phospholipids to modify the membrane composition and, as a consequence, the structure of the cortical cytoskeleton.

\section{Materials and Methods}

\section{Experimental design}

The experiments were performed on the spermatozoa and testes of C57Black6/J mice $(n=42)$. To simulate microgravity, the standard Ilyin-Novikov model of antiorthostatic rodent suspension with the Moray-Holton modification was applied [37]. All animals received a standard rodent feed, and water was provided ad libitum. Half of the animals $(\mathrm{n}=21)$ were randomly chosen to receive essential phospholipids in the form of Essentsiale ${ }^{\circledR}$ Forte N (A. Nattermann and Cie. GmbH, Germany) at a dosage of $500 \mathrm{mg} / \mathrm{kg} / \mathrm{day}$ for 10 days before the beginning of the experiment and for 30 days afterwards.

The following six groups were formed:

- $\quad$ group ( $\mathrm{n}=7$ ): reference group (mass = $28.2 \pm 0.7 \mathrm{~g}$ );

- $\quad$ CE group $(n=7)$ : reference group + essential phospholipids (mass = 28.4 $\pm 0.5 \mathrm{~g}$ );

- $\quad 30 H S$ group $(n=7)$ : suspension group ( $m=26.1 \pm 0.9 \mathrm{~g})$;

- $\quad 30 H S E$ group $(n=7)$ : suspension group + essential phospholipids (mass = 23.9 $\pm 0.9 \mathrm{~g}$ );

- $\quad 30 \mathrm{HS}+12 \mathrm{~h}$ group $(\mathrm{n}=7)$ : group with a 12-h recovery period after the 30-day suspension period (mass = 26.0 $\pm 0.6 \mathrm{~g})$;

- $\quad 30 H S E+12 \mathrm{~h}$ group $(\mathrm{n}=7)$ : group with a 12 -h recovery period after the 30 -day suspension period + essential phospholipids (mass $=25.2 \pm 0.9 \mathrm{~g}$ ).

After euthanizing the animals, the testes were extracted. The left testis was weighed and immediately frozen for subsequent protein and mRNA extractions. The caudal epididymis, from which the spermatozoa were extracted, was excised from the right testis.

All procedures with animals were approved by the Biomedical Ethics Committee of the State Scientific Center of the Russian Federation Institute of Biomedical Problems of the Russian Academy of Sciences (SSC RF-IMBP RAS; Protocol No. 425; June 20, 2016).

Sperm extraction and analysis of their motility and morphology

Immediately after extraction, the epididymis was placed in $1 \mathrm{ml} \alpha$-MEM medium with $10 \%$ bovine serum heated to $37^{\circ} \mathrm{C}$. Then, it was ground and incubated on a shaker (Thermo Shaker PST-60HL-4, Biosan, South Korea) for $30 \mathrm{~min}$ at $37^{\circ} \mathrm{C}$. The resulting suspended material was filtered through nylon filters with a mesh diameter of $70 \mu \mathrm{m}$. Some of the spermatozoa were frozen for subsequent protein and mRNA extractions. The motility and morphology of the remaining spermatozoa were analyzed.

To calculate the total number and the percentage of motile spermatozoa, a drop of the suspension was applied to a Makler chamber (Sefi Medical Instruments Ltd., Haifa, Israel) and observed in a phase-contrast microscope (Eclipse E200 MV, Nikon, Tokyo, Japan) with a magnification of 200× (Fig. 1A-F). For each sample, the total number and the number of mobile spermatozoa in 100 squares of the Makler chamber were counted at least three times. 


\section{Cellular Physiology \begin{tabular}{ll|l} 
and Biochemistry Published online: 17 November 2018 & $\begin{array}{l}\text { @ } 2018 \text { The Author(s). Published by S. Karger AG, Basel } \\
\text { www.karger.com/cpb }\end{array}$ \\
\hline
\end{tabular}

To analyze the number of viable spermatozoa and the permeability of their membranes, eosin staining was used. The stained cells were considered not viable, and the unstained cells were deemed viable (Fig. 1G-L). A minimum of 200 spermatozoa were studied for each sample under a light microscope with a magnification of $400 \times$.

Spermatozoa smears were stained with Diff-Quick (Abris+, Moscow, Russia), which was used to determine the number of spermatozoa with normal morphology (Fig. 1M-R). For each sample, a minimum of 200 cells with normal and abnormal morphologies were examined by light microscopy with a magnification of $1,000 \times$. On the basis of an earlier investigation by Gohari et al. [38], a morphological disorder was defined as any abnormality in sperm appearance or the head, tail, and remaining cytoplasmic residues. The average numbers of viable spermatozoa and spermatozoa with normal morphology were calculated as percentages.

\section{Determination of protein content based on gel electrophoresis followed by immunoblotting}

Proteins were extracted from frozen sperm and testis tissue. Cells and tissues were homogenized in Laemmli buffer containing a protease inhibitor cocktail (Calbiochem, San Diego, CA). Denaturing electrophoresis on polyacrylamide gels was performed using the Laemmli method (Bio-Rad Laboratories, Hercules, CA). Based on the measured concentration, an equal amount of protein was placed into each well, separated by electrophoresis, and transferred to a nitrocellulose membrane [39]. The efficiency of the protein transfer was assessed by Ponceau S staining before the membrane was blocked with milk. The following specific primary monoclonal antibodies were used at the dilutions recommended by the manufacturers to determine the expression levels of each protein: rabbit antibodies against JARID1B (KDM5B) diluted 1:100 (Bioss Antibodies, Woburn, MA), protamine diluted 1:250 (Sigma-Aldrich, Darmstadt, Germany), and SPACA3 diluted 1:1000 (OriGene, Rockville, MD); and mouse antibodies against beta-actin diluted 1:300, gamma-actin diluted 1:100, alpha-actinin-1 diluted 1:100, alpha-actinin-4 diluted 1:100, and beta-tubulin diluted 1:100 (Santa Cruz Biotechnology, Inc., Santa Cruz, CA). Biotinylated goat antibodies were used as the secondary antibodies to detect rabbit IgG (Jackson ImmunoResearch Laboratories, Inc., West Grove, PA) and mouse IgG (Sigma-Aldrich) at dilutions of 1:10, 000 and 1:20,000, respectively. Afterwards, all membranes were treated with a solution of streptavidin conjugated with horseradish peroxidase (Sigma-Aldrich) that was diluted 1:10, 000. Protein bands were detected using 3, 3'-diaminobenzidine (Merck, Burlington, MA). ImageJ software was used to analyze the obtained data.

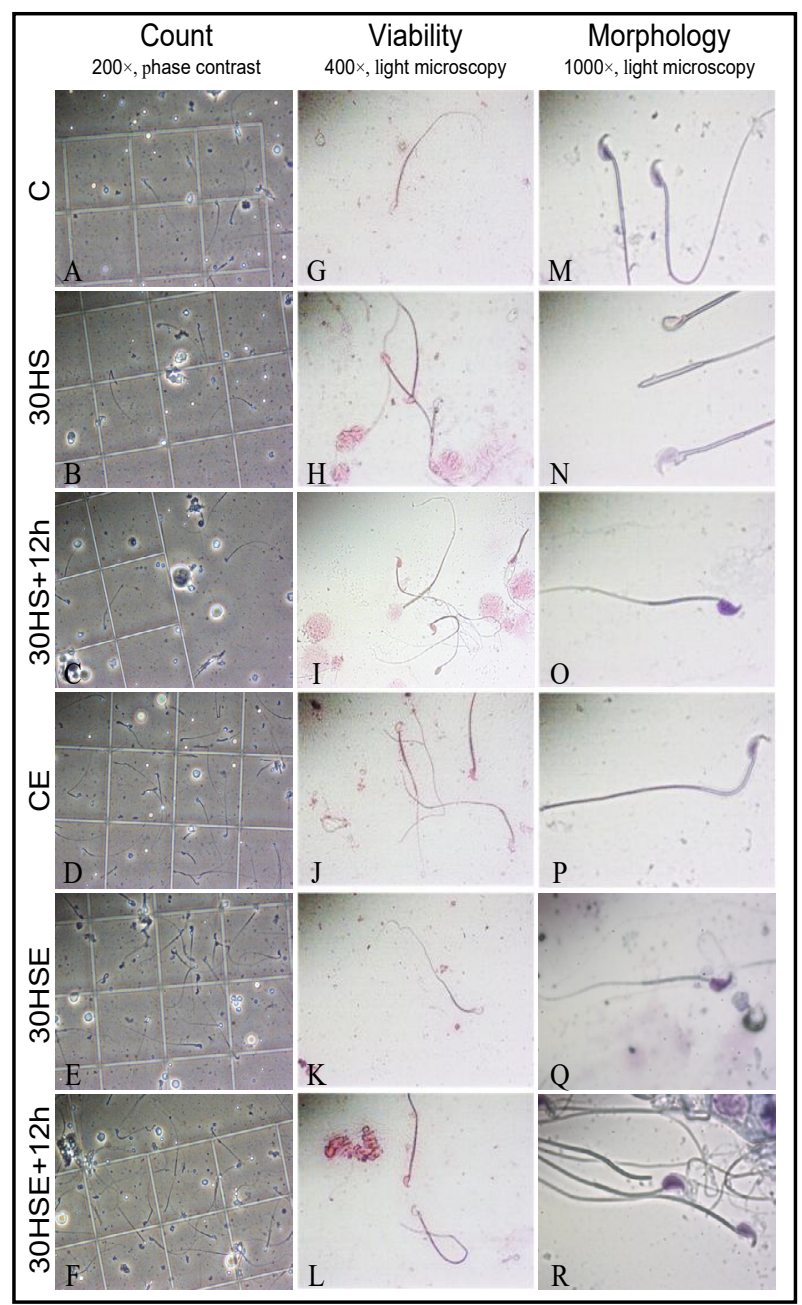

Fig. 1. Typical pictures for sperm count, viability and morphology. (A - F) Counts under phase contrast $(200 \times)$ for groups C, 30HS, 30HS+12h, CE, 30HSE, and 30HSE+12h, respectively. ( $\mathrm{G}-\mathrm{L}$ ) Viability determined by eosin staining under light microscopy $(400 \times)$ for groups C, 30HS, $30 \mathrm{HS}+12 \mathrm{~h}, \mathrm{CE}, 30 \mathrm{HSE}$, and $30 \mathrm{HSE}+12 \mathrm{~h}$, respectively. (M R) Viability determined by Diff-Quick staining under light microscopy with oil immersion $(1000 \times)$ for groups $\mathrm{C}, 30 \mathrm{HS}$, $30 \mathrm{HS}+12 \mathrm{~h}$, CE, 30HSE, and 30HSE+12 h, respectively. 


\section{Cellular Physiology Cell Physiol Biochem 2018;51:375-392 and Biochemistry \begin{tabular}{l|l} 
DOI: 10.1159/000495235 & $\begin{array}{l}\text { C } 2018 \text { The Author(s). Published by S. Karger AG, Basel } \\
\text { www.karger.com/cpb }\end{array}$
\end{tabular}

Table 1. Primer sequences and product sizes

\begin{tabular}{lcc}
\hline Gene & Primer sequence, forward/reverse (5'...3') & Product size, bp \\
\hline Actb (beta-actin) & gctgcgttttacaccctttc/gtttgctccaaccaactgct & 218 \\
Actg (gamma-actin) & ctggtggatctctgtgagca/tcaggagggaagaaaccaga & 184 \\
Actn1 (alpha-actinin 1) & ggtcagcagcaactcctc/tcttctccacttctctcca & 167 \\
Actn4 (alpha-actinin 4) & acctgaacagactccttg/gatcgacaagcctccatctc & 168 \\
Tubb2b (beta-tubulin 2B) & ggcagcaagaagctaacgag/cgaacacgaagttgtctggc & 302 \\
Kdm5b (lysine (K)-specific demethylase 5B, JARID1B) & agtggctttcctgttcgaga/ aagcacatgcccacatacaa & 173 \\
Prm1 (protamine 1) & atggccagataccgatgct/cgagatgctcttgaagtctgg & 231 \\
Spaca3 (sperm acrosome-associated 3, SLLP1) & caaggccaaggtcttcagtc/tcagcttcatgatccacagc & 150 \\
\hline
\end{tabular}

\section{Determination of $m R N A$ content using quantitative PCR}

Total RNA was isolated from frozen sperm and testis tissue using the RNeasy Micro Kit (Qiagen, Hilden, Germany) according to the manufacturer's instructions for a subsequent targeted analysis of the mRNA content of the genes encoding a number of cytoskeletal proteins and spermatozoid-specific proteins. Reverse transcription was performed using $\mathrm{d}(\mathrm{T})_{15}$, and $50 \mathrm{ng}$ RNA for sperm and 500 ng RNA for testis tissue were used as templates. The abundance of the resulting cDNA was measured. To avoid artifacts, all samples were analyzed with at least three replicates. Real-time PCR was performed using primers designed using Primer3Plus software (Table 1) to assess the expression levels of the studied genes. The $2^{-\Delta \Delta \mathrm{Ct}}$ method [40] was used to determine the expression level fold changes.

\section{Statistical analysis}

The protein and mRNA content data were statistically analyzed by analysis of variance and post hoc $t$-tests, and a significance level of $\mathrm{p}<0.05$ was applied to assess the reliability of differences between groups. Data are provided as the mean \pm standard error.

\section{Results}

\section{Testis mass}

The weight of the left testis was not significantly different between reference groups $\mathrm{C}$ and CE, with weights of $259 \pm 20 \mathrm{mg}$ and $237 \pm 23 \mathrm{mg}$, respectively. After the antiorthostatic suspension, as well as after the 12-h recovery period, the weight of the left testis was $27 \%$ lower in the 30HS group (188 $\pm 18 \mathrm{mg}$ ) and $32 \%$ lower in the $30 \mathrm{HS}+12 \mathrm{~h}$ group (177 \pm $16 \mathrm{mg}$ ) compared with the weight in the $C$ group (both $\mathrm{p}<0.05$ ). A similar decrease was observed in the suspension and recovery groups administered essential phospholipids, with decreases of 34\% (30HSE group, $m=171 \pm 21 \mathrm{mg}$ ) and 36\% (30HSE $+12 \mathrm{~h}$ group, $\mathrm{m}=165 \pm$ $15 \mathrm{mg}$ ) compared with the weight in the $\mathrm{C}$ group (both $\mathrm{p}<0.05$ ). There were no significant differences between the suspension groups with or without the 12-h recovery period.

\section{Sperm motility and morphology}

The number of sperm decreased significantly $(\mathrm{p}<0.05)$ by $45 \%$ in the $30 \mathrm{HS}$ group and by $51 \%$ in the $30 \mathrm{HS}+12 \mathrm{~h}$ group compared with the reference group data (Fig. 2). Moreover, the percentage of mobile sperm in these groups decreased more than 5 -fold compared with that in the reference group.

The use of essential phospholipids resulted in a 34\% increase in the number of mature spermatozoa in the CE group compared with the $\mathrm{C}$ group $(\mathrm{p}<0.05)$. However, antiorthostatic suspension plus the administration of essential phospholipids with or without the 12-h recovery period did not result in a decrease in the number of mature spermatozoa. It should be noted that in the 30HSE group, the decrease in the percentage of mobile spermatozoa was similar to that in the $30 \mathrm{HS}$ group. Nevertheless, the spermogram parameters in the $30 \mathrm{HSE}+12 \mathrm{~h}$ group did not differ from those in the reference group.

Motility parameters were normal and similar for all studied groups. The proportion of progressively motile spermatozoa was $31.2 \pm 2.9 \%$ in the C group, $32.1 \pm 2.8 \%$ in the $30 \mathrm{HS}$ group, $30.5 \pm 2.6 \%$ in the $30 \mathrm{HS}+12 \mathrm{~h}$ group, $33.0 \pm 3.0 \%$ in the CE group, $32.3 \pm 2.7 \%$ in the $30 \mathrm{HSE}$ group, and $31.4 \pm 2.2 \%$ in the $30 \mathrm{HSE}+12 \mathrm{~h}$ group. 


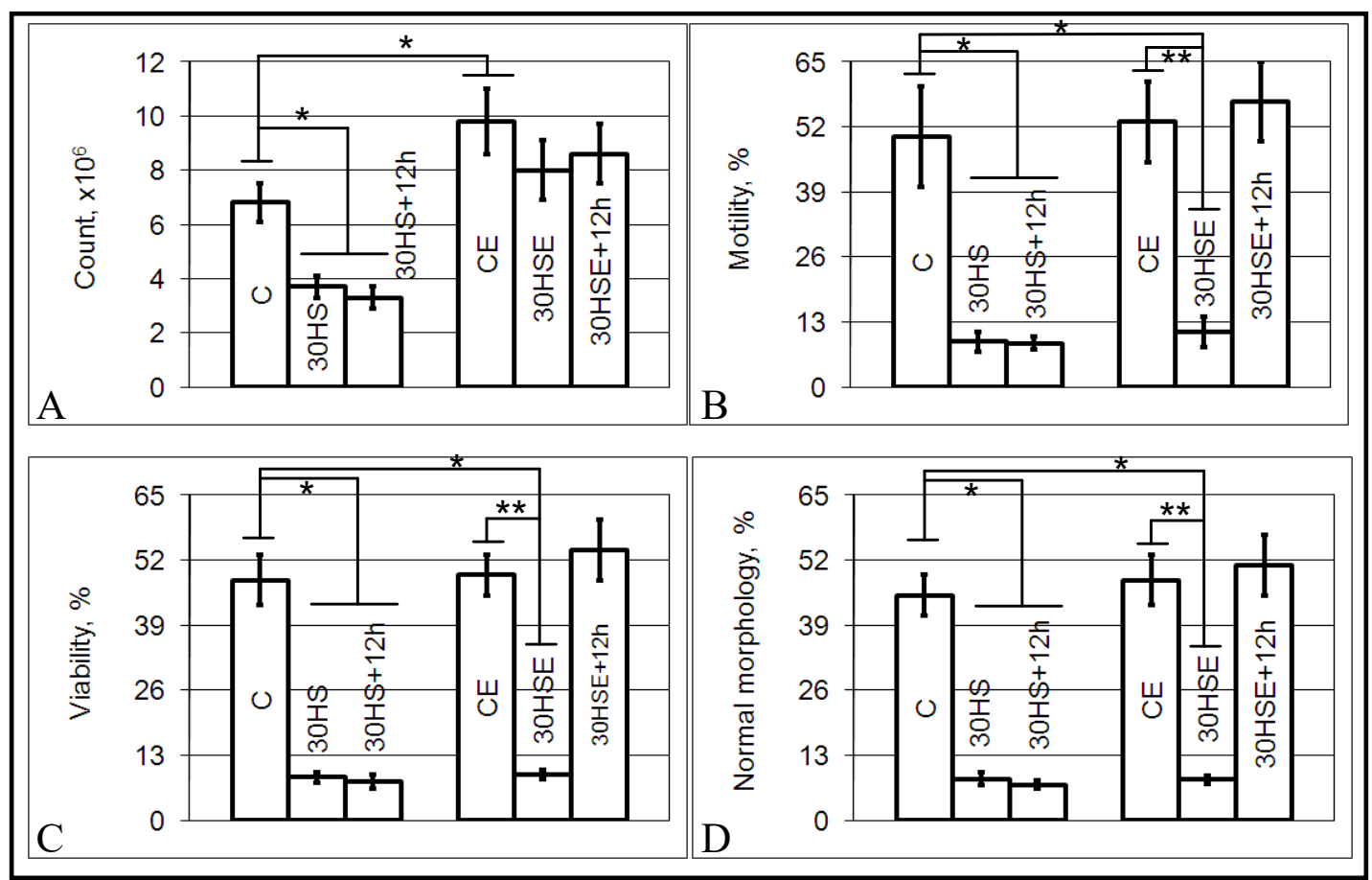

Fig. 2. Sperm parameters. (A) Count. (B) Motility. (C) Viability. (D) Normal morphology. *p<0.05 in comparison with the $\mathrm{C}$ group. ${ }^{* *} \mathrm{p}<0.05$ in comparison with the CE group.

Table 2. Distribution of the main spermatozoa morphological disorders

\begin{tabular}{|c|c|c|c|}
\hline $\begin{array}{l}\text { Part } \\
\text { Group }\end{array}$ & $\begin{array}{l}\text { Head (changes of shape, vesiculated } \\
\text { head), } \%\end{array}$ & $\begin{array}{l}\text { Midpiece (distal and proximal vesicula), } \\
\%\end{array}$ & $\begin{array}{c}\text { Tail (coiled tail), } \\
\%\end{array}$ \\
\hline $\mathrm{C}$ & $74 \pm 8$ & $8 \pm 2$ & $18 \pm 4$ \\
\hline $30 \mathrm{HS}$ & $78 \pm 9$ & $6 \pm 2$ & $16 \pm 3$ \\
\hline $30 \mathrm{HS}+12 \mathrm{~h}$ & $75 \pm 8$ & $7 \pm 3$ & $18 \pm 3$ \\
\hline $\mathrm{CE}$ & $79 \pm 7$ & $5 \pm 2$ & $16 \pm 4$ \\
\hline $30 \mathrm{HSE}$ & $72 \pm 6$ & $9 \pm 3$ & $19 \pm 4$ \\
\hline $30 \mathrm{HSE}+12 \mathrm{~h}$ & $75 \pm 7$ & $6 \pm 2$ & $19 \pm 3$ \\
\hline
\end{tabular}

In all studied groups, the percentages of viable spermatozoa and spermatozoa with normal morphology were correlated with the number of mobile spermatozoa. Most of the morphological changes were observed in the head (double-headed spermatozoa, elongated/ circular head, misshapen head, and vesiculated acrosome), but we did not observe any changes in these distributions after unloading in comparison with the control group (Table 2).

Sperm-specific protein and mRNA content in the sperm and testis tissue

The relative content of JARID1B remained at the reference level in all groups, except for the 30HS group, in which it was 15\% higher than in the reference group $(p<0.05)$ (Fig. 3,A, B). The protamine (Fig. 3C, D) and SPACA3 (Fig. 3E, F) content remained unchanged in both spermatozoa and testis tissue after 30 days of antiorthostatic suspension and $12 \mathrm{~h}$ of recovery.

The relative Jarid1B mRNA content in the spermatozoa of the $30 \mathrm{HS}, 30 \mathrm{HS}+12 \mathrm{~h}$, and 30 HSE groups was higher than the reference level by $114 \%, 101 \%$, and $34 \%$, respectively ( $p<0.05$ ) (Fig. 4A). At the same time, the Jarid1B mRNA content in the spermatozoa of the reference groups $\mathrm{C}$ and $\mathrm{CE}$ as well as the $30 \mathrm{HSE}+12 \mathrm{~h}$ group did not differ. Similarly, in the 
Fig. 3. Relative protein contents of spermspecific proteins in the sperm (SP) and testis tissue (TE) with typical western blots. (A), (B) Jarid1B. (C), (D) Prm. (E), (F) Spaca3. SP, sperm; TE, testis tissue. ${ }^{*} \mathrm{p}<0.05$ in comparison with the C group. ${ }^{* *} \mathrm{p}<0.05$ in comparison with the CE group. ${ }^{*} \mathrm{p}<0.05$ in comparison with the 30 HS group.

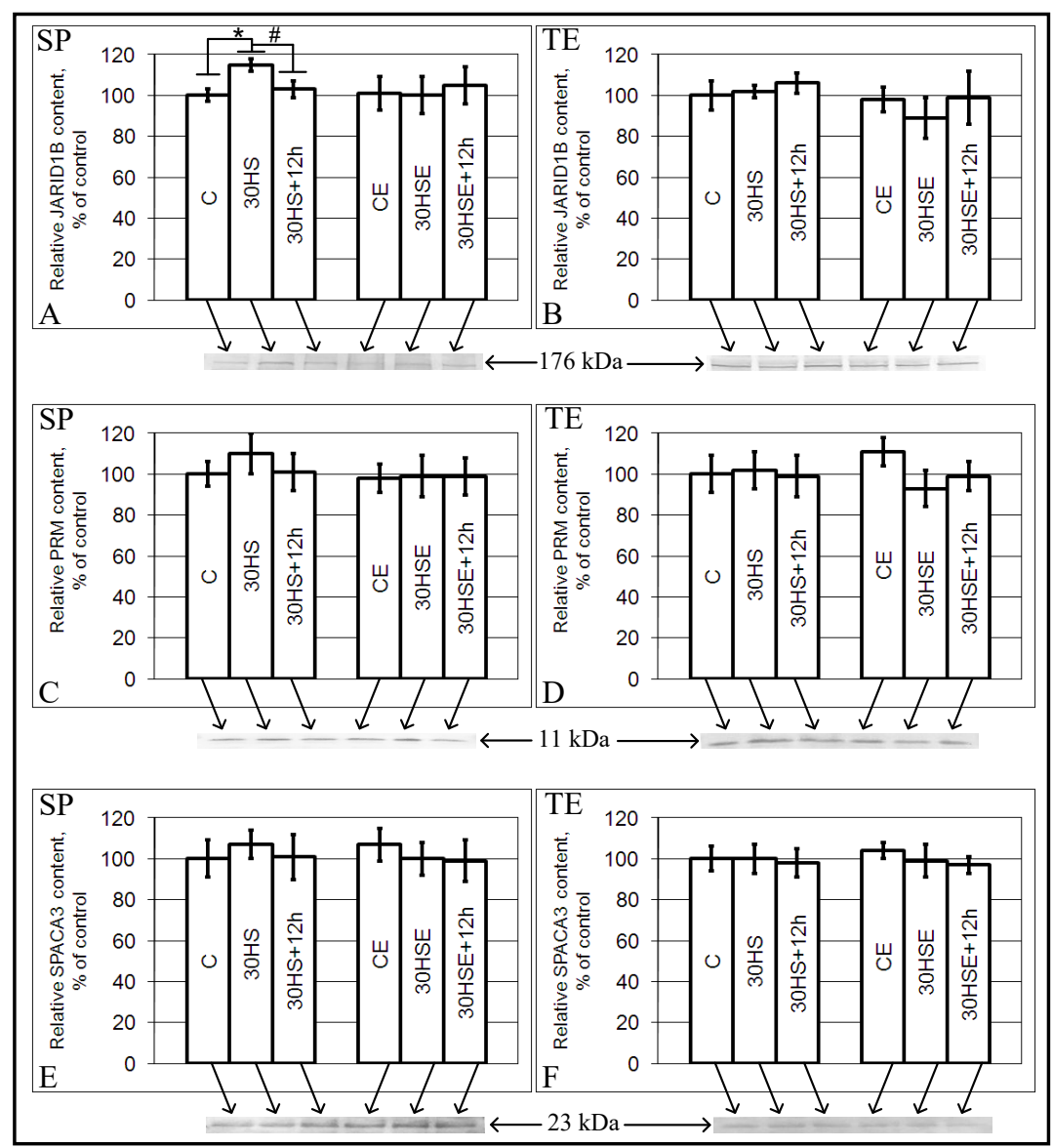

Fig. 4. Relative mRNA contents of genes encoding sperm-specific proteins in the sperm (SP) and testis tissue (TE). (A), (B) Jarid1B. (C), (D) Prm1. (E), (F) Spaca3. SP, sperm; TE, testis tissue. ${ }^{*} \mathrm{p}<0.05$ in comparison with the C group. ${ }^{* *} \mathrm{p}<0.05$ in comparison with the CE group. ${ }^{*} \mathrm{p}<0.05$ in comparison with the $30 \mathrm{HS}$ group.

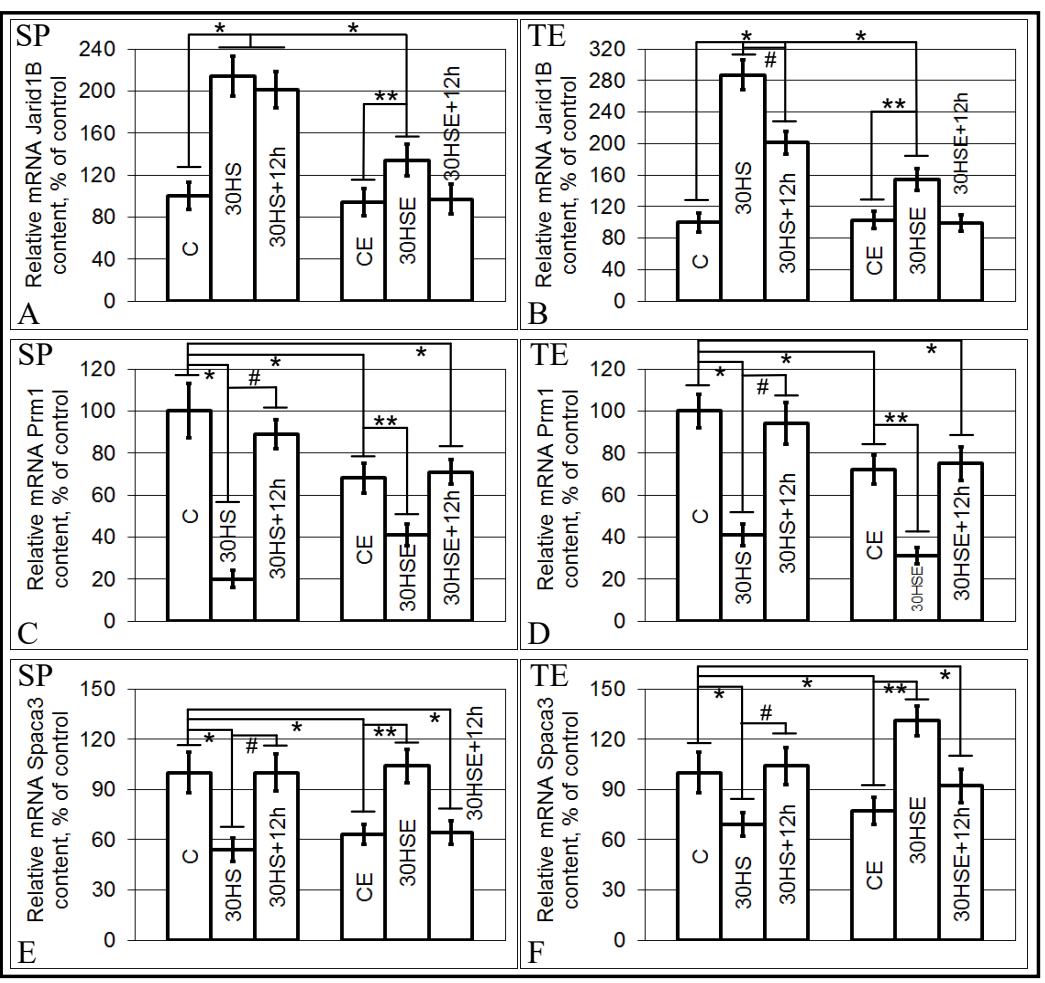


testis tissue (Fig. 4B), the relative Jarid1B mRNA content in the $30 \mathrm{HS}, 30 \mathrm{HS}+12 \mathrm{~h}$, and $30 \mathrm{HSE}$ groups was $187 \%, 101 \%$, and $54 \%$ higher than the reference level, respectively $(\mathrm{p}<0.05)$, while the Jarid $1 B$ mRNA content in the $\mathrm{C}, \mathrm{CE}$, and $30 \mathrm{HSE}+12 \mathrm{~h}$ groups did not differ.

Relative to the corresponding levels of the C group, the Prm 1 mRNA content in the spermatozoa (Fig. 4C) and the testis tissue (Fig. 4D) of the 30HS group was $80 \%$ and $59 \%$ lower, respectively (both $\mathrm{p}<0.05$ ), and they recovered to the reference levels after $12 \mathrm{~h}$ of recovery ( $30 \mathrm{HS}+12 \mathrm{~h}$ group). In the groups administered essential phospholipids, the dynamics were the same, but the content in the reference CE group was lower than in the $\mathrm{C}$ group by $32 \%$ and $28 \%$ in the spermatozoa and testis tissue, respectively (both $\mathrm{p}<0.05$ ).

Similar to the Prm1 mRNA content, the relative Spaca3 mRNA content decreased by $46 \%$ in the spermatozoa (Fig. 4E) and by $31 \%$ in the testis tissue (Fig. 4F) after 30 days of suspension (30HS) (both $\mathrm{p}<0.05$ ), and after $12 \mathrm{~h}$ of recovery $(30 \mathrm{HS}+12 \mathrm{~h}$ ), the levels

Fig. 5. Relative contents of m i c r of i la m e n t proteins in the sperm (SP) revealed by typical western blots. (A) Beta-actin. (B) Gamma-actin. (C) Alpha-actinin-1. (D) Alpha-actinin-4. \$p $<0.1$ in comparison with the $\mathrm{C}$ group.

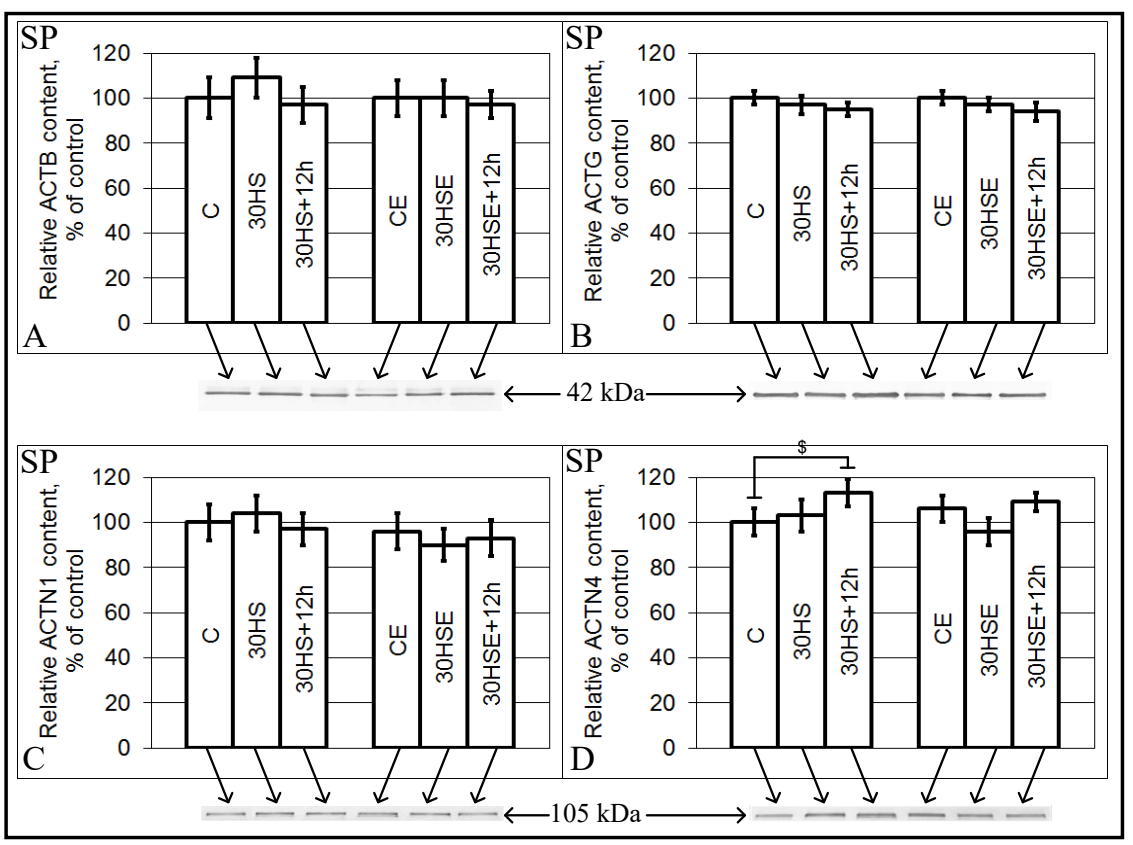

Fig. 6. Relative contents of $\mathrm{micr}$ of i la m e n $\mathrm{t}$ proteins in the testis tissue (TE) revealed by typical western blots. (A) Betaactin. (B) Gammaactin. (C) Alphaactinin-1. (D) Alphaactinin-4. ${ }^{*} \mathrm{p}<0.05$ in comparison with the $C$ group. ${ }^{*} p<0.05$ in comparison with the $30 \mathrm{HS}$ group.

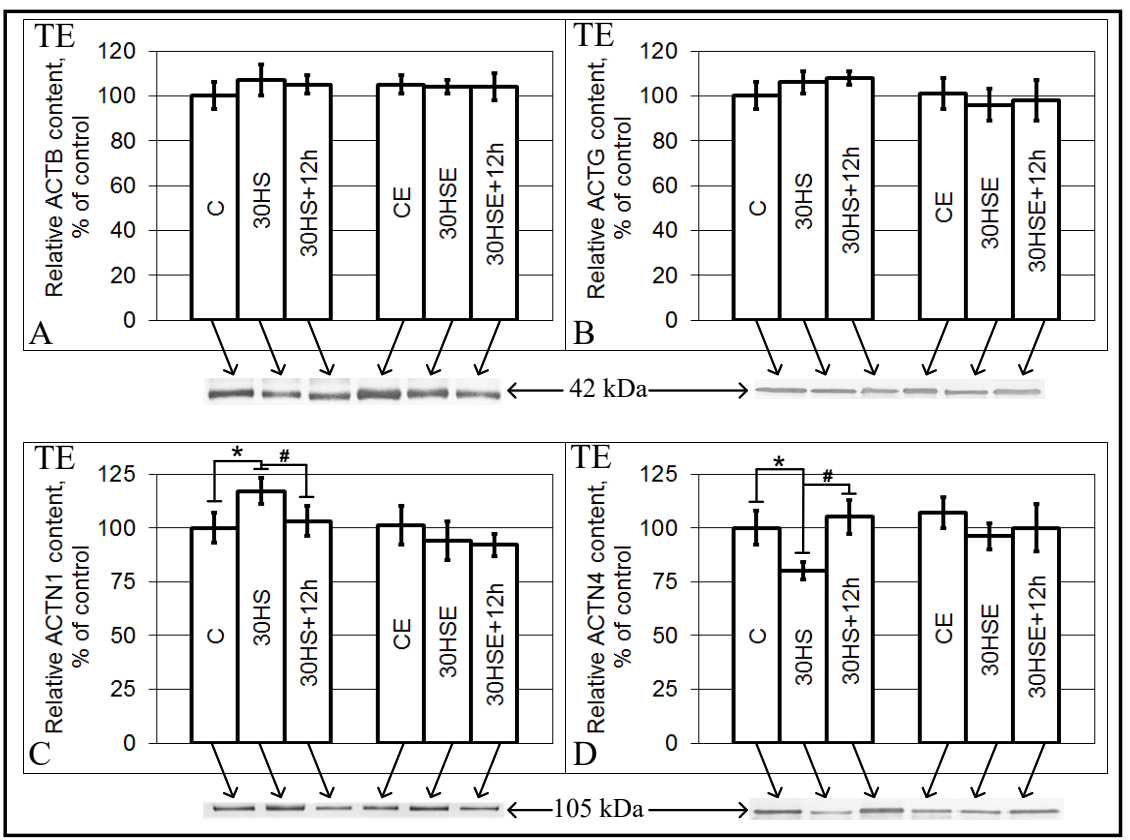




\section{Cellular Physiology \\ \begin{tabular}{rl|l} 
and Biochemistry & $\begin{array}{l}\text { DOI: } 10.1159 / 000495235 \\
\text { Published online: } 17 \text { November } 2018\end{array}$ \\
$\begin{array}{l}\text { Usik et al.: Cytoskeleton Structure in Mouse Sperm and Testes in Modeled Microgravity } \\
\text { www.karger.com/cpb }\end{array}$
\end{tabular}}

recovered to the reference levels. The relative mRNA content was $37 \%$ lower in the spermatozoa and $23 \%$ lower in the testis tissue in the CE reference group compared with the $\mathrm{C}$ group (both $\mathrm{p}<0.05$ ). In the $30 \mathrm{HSE}$ suspension group, the Spaca3 mRNA content increased to the reference level in the spermatozoa (Fig. 4E) and exceeded the reference level by $31 \%$ in the testis tissue $(\mathrm{p}<0.05$ ) (Fig. 4F). In the 30HSE $+12 \mathrm{~h}$ group, the Spaca3 mRNA content in the spermatozoa decreased to the level of the CE group, while in the testis tissue, it decreased to the level of the $\mathrm{C}$ group.

\section{Relative cytoskeletal protein content in sperm and testis tissue}

The relative content of the actin isoforms ACTB (Fig. 5A), ACTG (Fig. 5B), and the actinbinding protein ACTN1 (Fig. 5C) remained the same in the spermatozoa of all study groups. The content of another actin-binding protein, ACTN4 (Fig. 5D), tended to increase by 13\% in the $30 \mathrm{HS}+12 \mathrm{~h}$ group compared with the $\mathrm{C}$ group ( $\mathrm{p}<0.1$ ), while in groups administered essential phospholipids, it remained the same.

In the testis tissue, the relative content of the actin isoforms ACTB (Fig. 6A) and ACTG (Fig. 6B) was the same. The same was true in the spermatozoa. The ACTN1 (Fig. 6C) content was $17 \%$ higher in the 30 HS group than in the C group $(p<0.05)$, and after $12 \mathrm{~h}$ of recovery, the level had decreased to the reference level. In contrast, the ACTN4 content (Fig. 6D) in the $30 \mathrm{HS}$ group was $20 \%$ lower than the reference level $(\mathrm{p}<0.05)$, and increased to the reference level after $12 \mathrm{~h}$ of recovery. In groups administered essential phospholipids (30HSE and 30HSE+12h), the relative content of ACTN1 and ACTN4 did not differ from the reference levels.

The relative beta-tubulin content was similar in the reference $\mathrm{C}$ group and the reference group administered the essential phospholipids, CE. In the 30HS group after the 30 -day suspension and in the $30 \mathrm{HS}+12 \mathrm{~h}$ group after the 30 -day suspension with a subsequent 12 -h recovery period, the beta-tubulin content decreased by $19 \%$ and $22 \%$, respectively ( $\mathrm{p}<$ $0.05)$. In the similar groups administered essential phospholipids, 30HSE and 30HSE+12h, the beta-tubulin content decreased by $27 \%$ and $33 \%$, respectively ( $p<0.05$ ) (Fig. 7A). In the testis tissue, the relative beta-tubulin content did not change in any of the experimental groups (Fig. 7B).

Relative mRNA content of genes that encode cytoskeletal proteins in sperm and testis tissue

The relative beta-actin mRNA content remained the same in the spermatozoa (Fig. 8A) and testis tissue (Fig. 8B) in all study groups.

The relative gamma-actin mRNA content did not differ between the spermatozoa of the $30 \mathrm{HS}$ group and those of the $\mathrm{C}$ group, while it was $54 \%$ higher in the spermatozoa of the $30 \mathrm{HS}+12 \mathrm{~h}$ group than in the spermatozoa of the $\mathrm{C}$ group $(\mathrm{p}<0.05)$. In the groups administered essential phospholipids (CE, 30HSE, and 30HSE $+12 \mathrm{~h}$ ), the Actg mRNA content remained the same and did not differ from that of the $\mathrm{C}$ group (Fig. $8 \mathrm{C}$ ). There was no change in the relative gamma-actin mRNA content in the testis tissue (Fig. 8D).

Fig. 7. Relative content of betatubulin revealed by typical western blots. (A) SP, sperm. (B) TE, testis tissue. ${ }^{*} \mathrm{p}<0.05$ in comparison with the C group. ${ }^{* *} \mathrm{p}<0.05$ in comparison with the

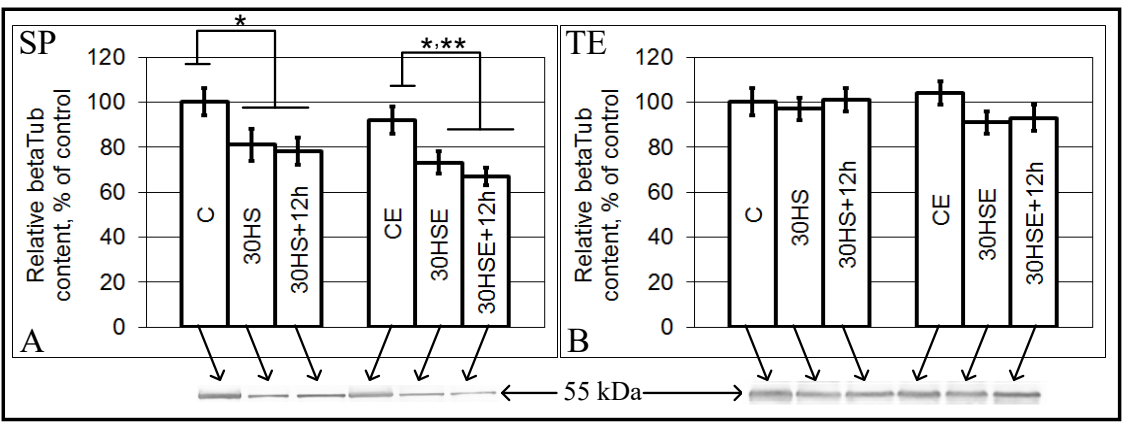
CE group. 
Fig. 8. Relative mRNA contents of genes encoding cytoskeletal proteins in the sperm (SP) and testis tissue (TE). (A), (B) Beta-actin. (C), (D) Gamma-actin. (E), (F) Alpha-actinin-1. (G), (H) Alpha-actinin-4. (I), (J) Beta-tubulin. SP, sperm; TE, testis tissue. ${ }^{*} \mathrm{p}<0.05$ in comparison with the $\mathrm{C}$ group. ${ }^{* *} \mathrm{p}<0.05$ in comparison with the CE group. ${ }^{*} \mathrm{p}<0.05$ in comparison with the $30 \mathrm{HS}$ group.

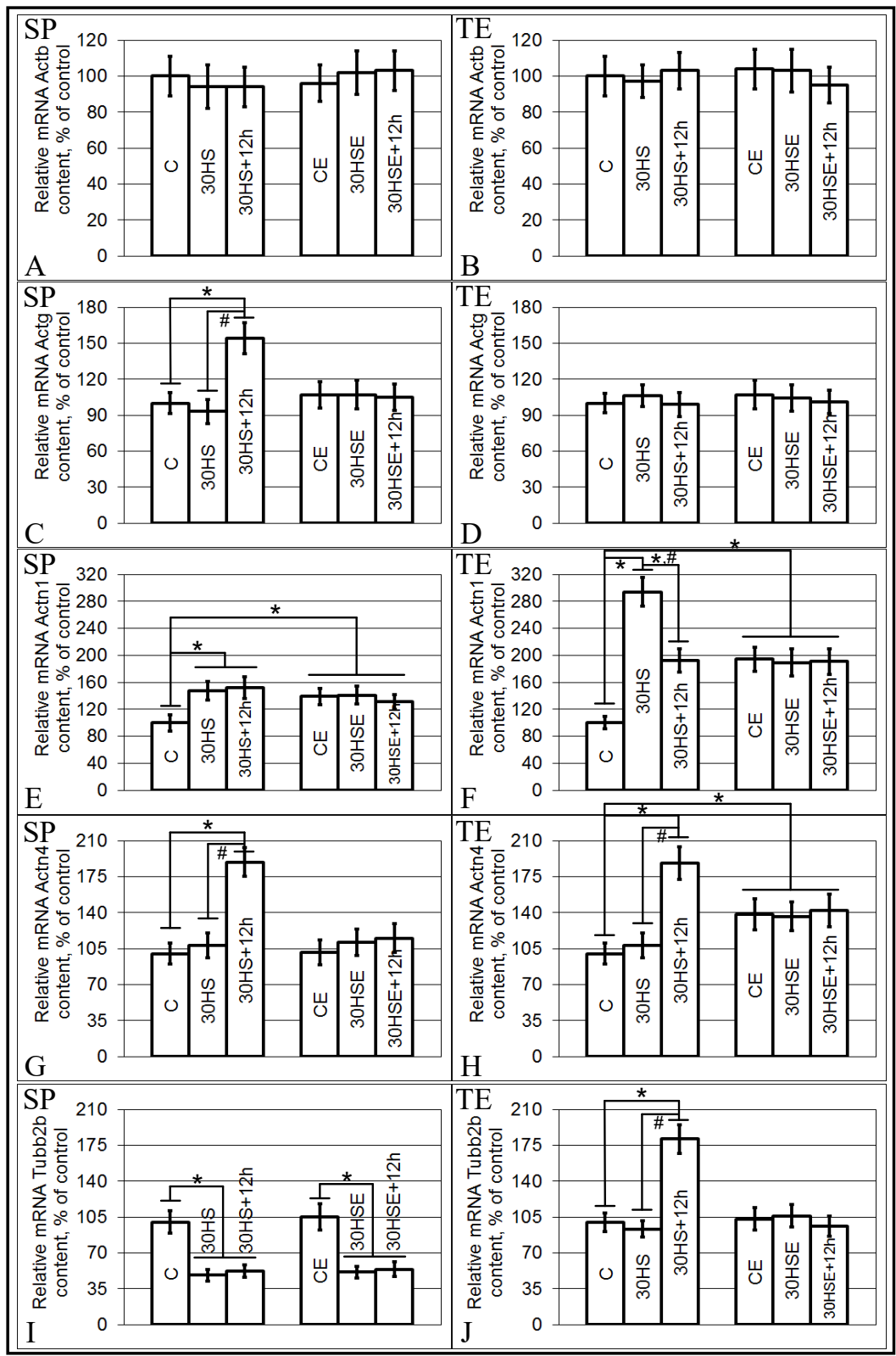

The Actn1 mRNA content in the spermatozoa of the 30HS group was $47 \%$ higher than that of the $C$ group ( $<<0.05)$, and in the $30 H S+12 h$ group, it was $52 \%$ higher $(p<0.05)$. In the spermatozoa of the CE, 30HSE, and 30HSE $+12 \mathrm{~h}$ groups, the Actn1 mRNA content was not significantly different, although it was 39\%, 41\%, and 31\% higher, respectively, than in the spermatozoa of the $\mathrm{C}$ group (all $\mathrm{p}<0.05$ ) (Fig. 8E). In the testis tissue in the $30 \mathrm{HS}$ group, the Actn1 mRNA content was 194\% higher than in the reference group ( $<<0.05)$, and after 12 $\mathrm{h}$ of recovery, it significantly decreased, although it still exceeded the reference level by $92 \%$ ( $p<0.05$ ) (Fig. 8F). As in the spermatozoa, the Actn1 mRNA content was not significantly different in the testis tissue of the CE, 30HSE, and $30 \mathrm{HSE}+12 \mathrm{~h}$ groups, but was $94 \%, 89 \%$, and $91 \%$ higher, respectively, than in the testis tissue of the $\mathrm{C}$ group (all $\mathrm{p}<0.05$ ).

The relative Actn 4 mRNA content in the spermatozoa (Fig. 8G) and testis tissue (Fig. 8H) of the $30 \mathrm{HS}$ group did not differ from that of the C group. In the $30 \mathrm{HS}+12 \mathrm{~h}$ group, it was $89 \%$ higher than the reference level in the spermatozoa and $88 \%$ higher than the reference level in the testis tissue (both $\mathrm{p}<0.05$ ). In the spermatozoa of the CE, 30HSE, and 30HSE+12h 


\section{Cellular Physiology \\ \begin{tabular}{rl|l} 
and Biochemistry & $\begin{array}{l}\text { DOI: } 10.1159 / 000495235 \\
\text { Published online: } 17 \text { November } 2018\end{array}$ \\
$\begin{array}{l}\text { Usik et al.: Cytoskeleton Structure in Mouse Sperm and Testes in Modeled Microgravity } \\
\text { www.karger.com/cpb }\end{array}$
\end{tabular}}

groups, the Actn 4 mRNA content was the same as that in the spermatozoa of the $\mathrm{C}$ group (Fig. $8 \mathrm{G}$ ). The Actn 4 mRNA content was 38\%, 36\%, and $42 \%$ higher in the testis tissue of the CE, $30 \mathrm{HSE}$, and $30 \mathrm{HSE}+12 \mathrm{~h}$ groups, respectively, than in the testis tissue of the $\mathrm{C}$ group (all $\mathrm{p}<$ 0.05) (Fig. 8H).

In the spermatozoa of the suspension and subsequent recovery groups, the relative beta-tubulin $(T u b b 2 b)$ mRNA content was lower than the reference level (the levels in the $\mathrm{C}$ and CE groups did not differ) by $52 \%$ in the $30 \mathrm{HS}$ group, by $48 \%$ in the $30 \mathrm{HS}+12 \mathrm{~h}$ group, by $49 \%$ in the $30 \mathrm{HSE}$ group, and by $46 \%$ in the $30 \mathrm{HSE}+12 \mathrm{~h}$ group (all $\mathrm{p}<0.05$ ) (Fig. $8 \mathrm{I}$ ). There was no change in the testis tissue, except in the $30 \mathrm{HS}+12 \mathrm{~h}$ group, wherein the beta-tubulin mRNA content exceeded the reference level by 81\% ( $<<0.05)$ (Fig. 8J).

\section{Discussion}

Investigations into the effects of microgravity on the structural and functional states of sex cells and germinal tissue cells can help elucidate the effects of gravity on embryogenesis and the early development of animals. Therefore, in this study, we evaluated the cytoskeletal protein content and associated mRNA levels in the spermatozoa and testes of mice after a 30-day simulation of the effects of microgravity through antiorthostatic suspension, during which time, some of the mice were orally administered essential phospholipids. In addition, the resulting spermogram required the determination of the mRNA and protein content at different stages of spermatogenesis.

\section{Testis weight and spermogram}

After 30 days of antiorthostatic suspension, testis weight decreased and did not recover after $12 \mathrm{~h}$. These changes could be caused by the combined effects of many factors, such as a lack of blood supply to the genital organs, primarily due to shifts in the fluid volume of the body in the cranial direction [41], as well as a change in hormonal regulation due to steroid hormones (testosterone) and gonadotropins (luteinizing hormone [LH] and folliclestimulating hormone [FSH]). However, the influence of the latter factor is unlikely because the 6-week suspension of male rats resulted in decreased testis weight and spermatogenesis; however, the levels of hormones controlling spermatogenesis (testosterone, FSH, and LH) remained within normal limits [27].

Nevertheless, our results also indicated that administering essential phospholipids may prevent a decrease in spermatogenesis. On the one hand, such a decrease may be due to an increase in apoptosis, which was observed after 7 days of antiorthostatic suspension [42]. On the other hand, a decrease in the number of mature spermatozoa may be associated with a change in the mRNA and protein levels of genes that control the differentiation of progenitor cells or the increase in apoptosis. Therefore, we estimated the relative protein and mRNA contents of the genes that were expressed at specific stages of spermatogenesis (genes encoding JARID1B for spermatogonia, protamine for spermatids, and SPACA3 for mature spermatozoa).

\section{Sperm-specific proteins and their expression levels}

The histone demethylase that demethylates "Lys-4" of histone H3, namely PLU-1/ KDM5B/JARID1B, is expressed in various cell types such as hematopoietic stem cells [43], neural precursors, and embryonic stem cells [44]. Moreover, it is highly expressed in the mitotic spermatogonia $[45,46]$. That is why we estimated its content as a marker of spermatogonia stem cells. Genes with expression levels stimulated by the JARID1B protein are involved in the maintenance of proliferation processes and the suppression of the expression of the genes responsible for terminating the cell cycle. It is believed that the differentiation of spermatogonia into spermatocytes is associated with the inactivation of the Jarid1B gene [47]. Our findings indicate that the JARID1B protein and associated mRNA content is higher after antiorthostatic suspension than in the reference group. This suggests there is a 


\section{Cellular Physiology \\ \begin{tabular}{ll|l} 
and Biochemistry & $\begin{array}{l}\text { DOI: 10.1159/000495235 } \\
\text { Published online: } 17 \text { November } 2018\end{array}$ & $\begin{array}{l}\text { (c) } 2018 \text { The Author(s). Published by S. Karger AG, Base } \\
\text { www.karger.com/cpb }\end{array}$ \\
\hline Usik et al: Cytoskeleton Structure in Mouse Sperm and Testes in Modeled Microgravity
\end{tabular}}

decrease in the cell differentiation potential and a cell cycle arrest in spermatogonia, which in turn, can lead to the decrease in the number of mature spermatozoa that we observed in the $30 \mathrm{HS}$ group. In this case, after $12 \mathrm{~h}$ of recovery, their expression levels returned to the reference level.

We used protamines as spermatid markers [48]. Protein content remained unchanged in all study groups, but the relative mRNA content decreased in the suspension groups and was restored to the reference level after a 12-h recovery period. We can assume that such regulation is carried out at the translational level, apparently contributing to the normalization of the protein pattern because of its exceptional physiological effects. Protamines are necessary for the high packing density of chromosomes, which minimizes the size and improves the hydrodynamic properties of the mature spermatozoon [48]. A decrease in the protamine content can be extremely important in early embryogenesis, leading to the formation of an abnormal pattern of gene expression, because it is assumed that after the fusion of the gametes, only genes with promoters and enhancers linked to histone proteins are initially expressed $[49,50]$. Thus, these results suggest that the chromatin structure may be changed in response to antiorthostatic suspension. It is well known that under conditions of real space flight and various microgravity models, oxidative stress occurs due to the accumulation of reactive oxygen species and nitrogen oxide [51]. In turn, oxidative stress is one of the most well-studied factors leading to chromatin damage in spermatozoa [52, 53], especially if the hormone concentrations are stable, there is a lack of toxic effects, and so on. Nevertheless, we did not observe a redistribution of morphological abnormalities after suspension, and the proportion of spermatozoa with an abnormal head did not differ in all study groups. However, we considered all spermatozoa with an abnormal head, without evaluating the proportion of double headed spermatozoa, misshapen heads, etc. Thus, an increase in the number of spermatozoa with damaged chromatin was not excluded. However, this hypothesis can only be confirmed by an explicit evaluation of the integrity of the chromatin (for example, by using the TUNEL method and HALO-SPERM method).

As well as protamines, sperm lysozyme-like protein 1 (SLLP1, SPACA3) contributes greatly to fertility. It participates in the fusion of gametes [54] and could be a marker of mature spermatozoa. The relative abundance of the SPACA3 protein, which is localized in the acrosomal vesicle of mature spermatozoa, was unchanged in all study groups. At the same time, its mRNA content decreased in the 30 HS group but was restored to the reference level after a 12-h recovery. This supports the hypothesis that the regulation may occur at the translational level.

Thus, the spermogram was correlated with the changes in the protein and mRNA content of the corresponding genes, the expression levels of which were typical for various stages of spermatogenesis; however, the reasons for such changes and, especially, the reasons for the recovery of the expression to reference levels after $12 \mathrm{~h}$ of recovery remain unclear. It can be assumed that a change in the orientation of the genital organs in the field of gravity and fluid shift, as well as the consequent change in the external mechanical stress, can result in an intracellular response and, therefore, a change in the gene expression pattern.

Previously, we assumed that the initial acts of mechanotransduction may be associated with the dissociation of the actin-binding proteins from the cortical cytoskeleton, such that with a decrease in external mechanical stress, alpha-actinin- 4 may migrate, and in the case of an increase, alpha-actinin-1 may migrate. On the basis of the above evidence, we decided to evaluate the content of various cytoskeletal proteins and the associated mRNA.

\section{mRNA and protein expression levels of cytoskeletal genes}

The total beta- and gamma-actin protein content, as well as the mRNA content of the corresponding genes, did not change significantly relative to the levels in the postsuspension and recovery reference groups. However, the abundance of the actin-binding proteins and, especially, the mRNA content of the corresponding genes did change. In the testes, the alpha-actinin-1 protein content after suspension was higher than in the reference group and decreased after a 12-h recovery period, as did the content of the corresponding 


\section{Cellular Physiology and Biochemistry

mRNA. Conversely, the alpha-actinin- 4 protein content decreased after suspension and then increased to the reference level after a 12 -h recovery period. In the spermatozoa, an increase in the alpha-actinin-4 protein content was observed only after a 12-h recovery period; however, changes in the mRNA content of actin-binding proteins were similar to those observed in the testes. Alpha-actinin-4 interacts with the focal-adhesive complex, ensuring it is connected to the actin cytoskeleton [55]. This connection supports the activity of the focaladhesive kinase, which provides the acrosome the integrity necessary for capacitation [56]. Consequently, changes in the alpha-actinin-4 content in spermatozoa can have significant consequences for their fertilization ability.

At the same time, there was no change in the tubulin cytoskeleton in the testes as well as in other types of cells during changes in gravity [36]. In contrast, in the spermatozoa, there were decreases in the protein and mRNA content that did not recover after a 12-h recovery period. A decrease in the tubulin content can result in problems with the differentiation of male germ cells because tubulin participates in the formation of the cleavage spindle during cell division [57], which, along with changes in the expression patterns of the sperm-specific genes, can result in a shift of the cellular profile towards immature forms. In addition, a decrease in the number of tubulin molecules can cause the formation of defective microtubules in the tail of the spermatozoon and lead to defective motility, as well as the disruption of the acrosomal reaction during fertilization [58]. However, we did not observe any changes to the motility characteristics (about $30-35 \%$ of spermatozoa exhibited progressive motility) or the redistribution of tail morphology abnormalities. We suggest that decreasing tubulin content was compensated by an increase in the efficiency of microtubule assembly in the axonema of the sperm tail, possibly at the expense of other cellular structures. This is only a suggestion and needs to be supported by direct evidence of changes in spermatozoon structure, especially the flagellum (maybe by electron microscopy).

It should be noted that the changes in the actin-binding protein content were more pronounced in the testis tissue than in the spermatozoa. Minor changes in the spermatozoa, with the exception of changes in tubulin, can be associated with a fundamentally different cell structure that is significantly more compact and, as a consequence, less susceptible to changes in external stress from a mechanical point of view. At the same time, an analysis of testis tissue revealed different types of cells. Most of these cells have developed cortical cytoskeletons and normal cytoplasm volumes, which may result in the dissociation of the actin-binding proteins and the initiation of intracellular signaling pathways to form the observed adaptive pattern of gene expression.

\section{Effect of the administration of essential phospholipids}

Administration of the essential phospholipids can lead to a decrease in the cholesterol content of different cell types [59]. It is well known that the cholesterol content in the lipid microdomains of plasma membranes (rafts) can modify the activity of ionic channels and the organization of the actin network [60-68]. Furthermore, a decrease in the cholesterol raft content in the membrane can result in a change in the ratio between the proteins anchored in the membrane and the proteins in the cytoplasm [69-70], with a significant effect on the expression of the genes encoding them. Thus, it can explain a phenomenon we observed in muscle cells [36] as well as in this study. Specifically, the relative content of mRNAs corresponding to the actin-binding proteins was higher in the reference group administered the essential phospholipids than in the reference group not administered the essential phospholipids.

Our previous measurements [36] showed that even unsaturated phosphatidylcholines (such as lecithin) can decrease the cytochrome $c$ content in the cytoplasmic fraction. Such a decrease may lead to a decrease in apoptosis [72]. The administration of essential phospholipids prevented changes in the JARID1B protein content and decreases in the spermatozoa count after hindlimb unloading, maybe due to a decreasing apoptosis level. However, the use of phospholipids did not prevent the decrease in motility, viability, and proportion of spermatozoa with normal morphology after suspension, but these parameters 


\section{Cellular Physiology

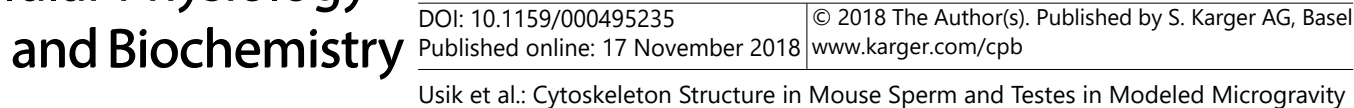

were restored after $12 \mathrm{~h}$ of recovery. Because most morphological changes are associated with spermatozoon head abnormalities (especially vesiculation of the acrosome), we can assume that a rapid recovery within $12 \mathrm{~h}$ may be associated with the altered phospholipid composition of the sperm membrane. Additionally, Spaca3 expression increased in the 30HSE group instead of decreasing like in the 30HS group. It should be noted that the acrosomal reaction in mammals, which is mediated by SPACA3, is impossible without capacitation, one of the stages in which the cholesterol content in the sperm membrane decreases $[73,74]$.

Despite the increasing spermatozoa count following the administration of essential phospholipids and a very short recovery period after gravitational unloading, we cannot say anything about their fertilization ability. However, it should be mentioned that strong evidence might be obtained from an experiment that estimates the acrosome reaction (for example, by acrosome reaction ionophore challenge) and zona pellucida binding.

\section{Conclusion}

The results obtained in this study indicate that following a 30-day antiorthostatic suspension and 12-h recovery, there were practically no changes in the expression patterns of cytoskeletal proteins and sperm-specific proteins in the spermatozoa of mice, except for a decrease in the tubulin protein content and an increase in the JARID1B protein content after the suspension. However, the relative mRNA content of the genes encoding cytoskeletal proteins and sperm-specific proteins did change. These data suggest that the regulation of protein expression patterns in spermatozoa under the conditions of a modified external mechanical field is mainly carried out at the translational level. In general, we observed multidirectional changes in the actin-binding protein content (alpha-actinin- 1 and alphaactinin-4) in the testes that were similar to those for other types of cells. The oral administration of phospholipids helped to prevent these changes and restore the spermogram parameters to the normal range within $12 \mathrm{~h}$; however, in the reference group, the administration of phospholipids resulted in an increase in the expression of cytoskeletal genes, a phenomenon that requires additional investigation. In addition, the oral administration of phospholipids leads to an increase in the number of spermatozoa in control mice, which also requires further study.

Limitations of this study were related to the phospholipid effects on spermogram parameters and sperm-specific gene expression. The rapid recovery of spermogram parameters within $12 \mathrm{~h}$ after a 30-day antiorthostatic suspension with phospholipids being administered should be characterized further in future studies focused on the chromatin state and fertilization ability of spermatozoa in general.

\section{Acknowledgements}

The authors express gratitude to Maria Kupriyanova, Nikolay Biryukov and Sergey Loktev for the technical assistance in carrying out the experiments.

The study was financially supported by the program for fundamental research SSC RF - IBMP RAS, program "Cell and Molecular Biology" of the RAS Presidium, Russian Academic Excellence Project 5-100.

\section{Disclosure Statement}

The authors declare that they have no conflicts of interest. 


\section{Cellular Physiology Cell Physiol Biochem 2018;51:375-392 \begin{tabular}{l|l|l|l|l} 
DO 2018 The Author(s). Published by S. Karger AG, Basel \\
and Biochemistry
\end{tabular}

\section{References}

1 Sakar D, Nagaya T, Koga K, Seo H: Culture in Vector-averaged Gravity Environment in a Clinostat Results in Detachment of Osteoblastic ROS 17/2.8 Cells. Environmental Medicine 1999;43:22-24.

2 Uva BM, Masini MA, Sturla M, Prato P, Passalacqua M, Giuliani M, Tagliafierro G, Strollo F: Clinorationinduced weightlessness influences the cytoskeleton of glial cells in culture. Brain Res 2002;934:132-139.

- G Gaboyard S, Blachard MP, Travo BT, Viso M, Sans A, Lehouelleur J: Weightlessness affects cytoskeleton of rat utricular hair cells during maturation in vitro. NeuroReport 2002;13:2139-2142.

-4 Plett PA, Abonour R, Frankovitz SM, Orschell CM: Impact of modeled microgravity on migration, differentiation and cell cycle control of primitive human hematopoietic progenitor cells. Experimental Hematology 2004;32:773-781.

5 Kacena MA, Todd P, Landis WJ. Osteoblasts subjected to spaceflight and simulated space shuttle launch conditions. In vitro Cell Dev Biol - Animal 2004;39:454-459.

6 Crawford-Young SJ: Effects of microgravity on cell cytoskeleton and embryogenesis. Int J Dev Biol 2006;50:183-191.

7 Schatten H, Lewis ML, Chakrabarti A: Spaceflight and clinorotation cause cytoskeleton and mitochondria changes and increases in apoptosis in cultured cells. Acta Astronautica 2001;49:399-418.

8 Gershovich PM, Gershovich JG, Buravkova LB: Simulated microgravity alters actin cytoskeleton and integrin-mediated focal adhesions of cultured human mesenchymal stromal cells. J Grav Physiol 2008;15:203-204

-9 Zayzafoon M, Gathings WE, McDonald JM: Modeled microgravity inhibits osteogenic differentiation of human mesenchymal stem cells and increases adipogenesis. Endocrinology 2004;145:2421-2432.

-10 Meyers VE, Zayzafoon M, Gonda SR, Gathings WE, McDonald JM: Modeled microgravity disrupts collagen I/ integrin signaling during osteoblastic differentiation of human mesenchymal stem cells. Journal of Cellular Biochemistry 2004;93:697-707.

-11 Meyers VE, Zayzafoon M, Douglas JT, McDonald JM: RhoA and cytoskeletal disruption mediate reduced osteoblastogenesis and enhanced adipogenesis of human mesenchymal stem cells in modeled microgravity. Journal of Bone and Mineral Research 2005;20:1858-1866.

12 Dai ZQ, Wang R, Ling SK, Wan YM, Li YH: Simulated microgravity inhibits the proliferation and osteogenesis of rat bone marrow mesenchymal stem cells. Cell Proliferation 2007;40:671-684.

13 Patel MJ, Liu W, Sykes MC, Ward NE, Risin SA, Risin D, Jo H: Identification of mechanosensitive genes in osteoblasts by comparative microarray studies using the rotating wall vessel and the Random Positioning Machine. Journal of Cellular Biochemistry 2007;101:587-599.

14 Pan Z, Yang J, Guo C, Shi D, Shen D, Zheng Q Chen R, Xu Y, Xi Y, Wang J: Effects of hindlimb unloading on ex vivo growth and osteogenic/adipogenic potentials of bone marrow derived mesenchymal stem cells in rats. Stem Cells and Development 2008;17:795-804.

15 Huang Y, Dai ZQ, Ling SK, Zhang HY, Wan YM, Li YH: Gravity, a regulation factor in the differentiation of rat bone marrow mesenchymal stem cells. Journal of Biomedical Science 2009;16:87, 14 pages.

16 Buravkova LB, Romanov YA, Konstantinova NA, Buravkov SV, Gershovich YG, Grivennikov IA: Cultured stem cells are sensitive to gravity changes. Acta Astronautica 2008;63:603-608.

17 Konstantinova NA, Buravkova LB, Manuilova ES, Grivennikov IA: The effects of gravity vector randomization on mouse embryonic stem cells in vitro. Journal of Gravitational Physiology 2006;13:149150.

18 Sordella R, Jiang W, Chen GC, Curto M, Settleman J: Modulation of Rho GTPase signaling regulates a switch between adipogenesis and myogenesis. Cell 2003;113:147-158.

19 McBeath R, Pirone DM, Nelson CM, Bhadriraju K, Chen CS: Cell shape, cytoskeletal tension, and RhoA regulate stem cell lineage commitment. Developmental Cell 2004;6:483-495.

20 Ontogenesis of Mammals in Microgravity, NASA TM 103978, 1993.

21 Serova LV, Natochkin IV, Nosovskii AM, Shakhmatova EI, Fast T: Effect of weightlessness on the motherfetus system (results of embryological experiment NIH-R1 abroad the "Space Shuttle". Aviakosm. Ekol. Med 1996;30:4-8.

-22 Savel'ev SV, Serova LV, Besova NV, Nosovskii AM: Effect of weightlessness on rats endocrine system development. Aviakosm. Ekol. Med 1998;32:31-36. 


\section{Cellular Physiology Cell Physiol Biochem 2018;51:375-392 \begin{tabular}{l|l|l}
\hline DOI: 10.1159/000495235 & (c) 2018 The Author(s). Published by S. Karger AG, Basel
\end{tabular} and Biochemistry Published online: 17 November 2018 www.karger.com/cpb \\ Usik et al.: Cytoskeleton Structure in Mouse Sperm and Testes in Modeled Microgravity}

-23 Serova LV. Microgravity and development of the mammals: problems, results, prospects. Aviakosm. Ekol. Med 2001;35:32-35.

-24 Kojima Y, Sasaki S, Kubota Y, Ikeuchi T, Hayashi Y, Kohri K: Effects of simulated microgravity on mammalian fertilization and preimplantation embryonic development in vitro. Fertil. Steril 2000;74:1142-1147.

$>25$ Serova LV. Effect of weightlessness on the reproductive system of mammals. Kosm. Biol. Aviakosm. Med 1989;23:11-16.

-26 Serova LV, Denisova LA, Apanasenko ZI, Kuznetsova MA, Meizerov ES. Reproductive function of the male rat after a flight on the Kosmos-1129 biosatellite. Kosm. Biol. Aviakosm. Med 1982;16:62-65.

-27 Tash JS, Johnson DC, Enders GC: Long-term (6wk) hindlimb suspension inhibits spermatogenesis in adult male rats. J. Appl. Physiol 2002;92:1191-1198.

28 Pellegrini M, Di Siena S, Claps G, Di Cesare S, Dolci S, Rossi P, Geremia R, Grimaldi P: Microgravity promotes differentiation and meiotic entry of postnatal mouse male germ cells. PLoS ONE 2010;5:e9064.

29 Di Agostino S., Botti F., Di Carlo A., Sette C., Geremia R: Meiotic progression of isolated mouse spermatocytes under simulated microgravity. Reproduction 2004;128:25-32.

-30 Tash JS, Bracho GE: Microgravity alters protein phosphorylation changes during initiation of sea urchin sperm motility. FASEB J 1999;13:S43-54.

31 Ogneva IV: The transversal stiffness of fibers and the desmin content in the leg muscles of rats under gravitational unloading of various duration. J Appl Physiol 2010;109:1702-1709.

-32 Ogneva IV: Cell mechanosensitivity: mechanical properties and interaction with gravitational field. BioMed Research International 2013;Article ID:598461, 17 pages.

-33 Ogneva IV, Biryukov NS, Leinsoo TA, Larina IM: Possible role of non-muscle alpha-actinins in muscle cell mechanosensitivity. PLoS ONE 2014;9:e96395.

-34 Ogneva IV, Maximova MV, Larina IM: Structure of cortical cytoskeleton in fibers of mousemuscle cells after being exposed to a 30-day space flight on board the BION-M1 biosatellite. J Appl Physiol 2014;116:13151323.

-35 Ogneva IV, Gnyubkin V, Laroche N, Maximova MV, Larina IM, Vico L: Structure of the cortical cytoskeleton in fibers of postural muscles and cardiomyocytes of mice after 30-day 2g-centrifugation. J Appl Physiol 2015;118:613-623.

-36 Ogneva IV, Biryukov NS: Lecithin prevents cortical cytoskeleton reorganization in rat soleus muscle fibers under short-term gravitational disuse. PLoS ONE 2016;11:e0153650.

37 Morey-Holton E, Globus RK, Kaplansky A, Durnova G: The hindlimb unloading rat model: literature overview, technique update and comparison with spaceflight data. Adv Space Biol Med 2005;10:7-40.

38 Gohari FA, Saranjam B, Asgari M, Omidi L, Ekrami H, Moussavi-Najarkola SA: An experimental study of the effects of combined exposure to microwave and heat on gene expression and sperm parameters in mice. J Hum Reprod Sci 2017;10:128-134.

-39 Towbin H, Staehlin T, Gordon J: Electrophoretic transfer of proteins from polyacrylamide gels to nitrocellulose sheets: procedure and some application. Proc Natl AcadSci USA 1970;76:4350-4354.

-40 Livak KJ, Schmittgen TD: Analysis of relative gene expression data using real-time quantitative PCR and the 2(-Delta Delta C(T)) method. Methods 2001;2:402-408.

41 Watenpaugh DE, Hargens AR: The cardiovascular system in microgravity. In Handbook of Physiology. Environmental Physiology, Am Physiol Soc, 4(vol. I, pt. 3, chapt. 29) 1996;631-674.

42 Kamiya H, Sasaki Sh, Ikeuchi T, Umemoto Y, Tatsura H, Hayashi Y, Kaneko Sh, Kohri K: Effect of simulated microgravity on testosterone and sperm motility in mice. J Androl 2003;24:885-890.

-43 Stewart MH, Albert M, Sroczynska P, Cruickshank VA, Guo Y, Rossi DJ, Helin K, Enver T: The histone demethylase Jarid1b is required for hematopoietic stem cell self-renewal in mice. Blood 2015;125:20752078.

44 Schmitz SU, Albert M, Malatesta M, Morey L, Johansen JV, Bak M, Tommerup N, Abarrategui I, Helin $\mathrm{K}$ : Jarid1 $\mathrm{b}$ targets genes regulating development and it is involved in neural differentiation. EMBO J 2011;30:4586-4600.

45 Madsen B, Tarsounas M, Burchell JM, Hall D, Poulsom R, Taylor-Papadimitriou J: PLU-1, a transcriptional repressor and putative testis-cancer antigen, has a specific expression and localization pattern during meiosis. Chromosoma 2003;112:124-132. 


\section{Cellular Physiology Cell Physiol Biochem 2018;51:375-392 and Biochemistry DOl: 10.1159/000495235 2018 (O) 2018 The Author(s). Published by S. Karger AG, Basel

46 Cui Y, Zhang Y, Wei Zh, Gao J, Yu T, Chen R, Lv X, Pan Ch: Pig KDM5B: mRNA expression profiles of different tissues and testicular cells and association analyses with testicular morphology traits. Gene 2018;650:2733.

-47 Simpson AJ, Caballero OL, Jungbluth A, Chen YT, Old LJ. Cancer/testis antigens, gametogenesis and cancer. Nat. Rev. Cancer 2005;5:615-625.

48 Depa-Martynow M, Kempisty B, Lianeri M, Jagodzinski PP, Jedrzejczak P: Association between fertilin beta, protamines 1 and 2 and spermatid-specific linker histone H1-like protein mRNA levels, fertilization ability of human spermatozoa, and quality of preimplantation embryos. Folia Histochem Cytobiol. 2007;45:S7985.

49 Aoki VW, Liu L, Carrell DT: A novel mechanism of protamine expression deregulation highlighted by abnormal protamine transcript retention in infertile human males with sperm protamine deficiency. Mol. Hum. Reprod 2006;12:41-50.

50 Balhorn R: The protamine family of sperm nuclear proteins. Genome Biol 2007;8:227, 8 pages.

51 Goodwin ThJ, Christofidou-Solomidou M: Oxidative stress and space biology: an organ-based approach. Int J Mol Sci 2018;19:959-969.

52 Omu AE: Sperm parameters: paradigmatic index of good health and longevity. Med Princ Prac 2013;22:3042.

53 Gatimel N, Moreau J, Parinaud J, Leandri RD: Sperm morphology: assessment pathophisiology, clinical relevance and state of the ART in 2017. Andrology 2017;5:845-862.

54 Lea IA, Widgren EE, O’Rand MG: Association of sperm protein 17 with A-kinase anchoring protein 3 in flagella. Reprod Biol Endocrinol 2004;2:57, 7 pages.

55 Baron MD, Davison MD, Jones P, Critchley DR: The structure and function of alpha-actinin. Biochem Soc Trans 1987;15:796-798.

-56 Roa-Espitia AL, Hernandez-Rendon ER, Baltierrez-Hoyos R, Munoz-Gotera RJ, Cote-Velez A, Jimenez I, Gonzalez-Marquez H, Hernandez-Gonzalez EO: Focal adhesion kinase is required for actin polymerization and remodeling of the cytoskeleton during sperm capacitation. Biol. Open 2016;5:1189-1199.

-57 Fackenthal JD, Turner FR, Raff EC: Tissue-specific microtubules functions in Drosophila spermatogenesis require the beta 2-tubulin isotype-specific carboxy terminus. Dev Biol 1993;158:213-227.

-58 Xia J, Reigada D, Mitchell CH, Ren D: CATSPER channel-mediated Ca2+ entry into mouse sperm triggers a tail-to-head propagation. Biol. Reprod 2007;77:551-559.

59 Jayaraman T, Kannappan S, Ravichandran MK, Anuradha CV: Impact of Essentiale L on ethanol induced changes in rat brain and erythrocytes. Singapore Med J 2008;49:320-327.

60 Harder T, Simons K: Clusters of glycolipid and glycosylphosphatidylinositol-anchored proteins in lymphoid cells: accumulation of actin regulated by local tyrosine phosphorylation. Eur J Immunol 1999;29:556-562.

61 Brown DA, London E: Structure and function of sphingolipid- and cholesterol-rich membrane rafts. J Biol Chem 2000;275:17221-17224.

62 Nebl T, Pestonjamasp KN, Leszyk JD, Crowley JL, Oh SW, Luna EJ: Proteomic analysis of a detergentresistant membrane skeleton from neutrophil plasma membranes. J Biol Chem 2002;277:43399-43409.

63 Brown DA: Lipid rafts, detergent-resistant membranes, and raft targeting signals. Physiology (Bethesda) 2006;21:430-439.

64 Levitan I, Christian AE, Tulenko TN, Rothblat GH: Membrane cholesterol content modulates activation of volume-regulated anion current in bovine endothelial cells. J Gen Physiol 2000;115:405-416.

65 Shlyonsky VG, Mies F, Sariban-Sohraby S: Epithelial sodium channel activity in detergent-resistant membrane microdomains. Am J Physiol Renal Physiol 2003;284:F182-188.

66 Edidin M: The state of lipid rafts: from model membranes to cells. Annu Rev Biophys Biomol Struct 2003;32:257-283.

67 Chubinskiy-Nadezhdin VI, Negulyaev YA, Morachevskaya EA: Cholesterol depletion-induced inhibition of stretch-activated channels is mediated via actin rearrangement. Biochem Biophys Res Commun 2011;412:80-85.

68 Morachevskaya EA, Sudarikova AV, Negulyaev YA: Mechanosensitive channel activity and F-actin organization in cholesterol-depleted human leukaemia cells. Cell Biol Int 2007;31:374-381.

69 Harder T, Simons K: Clusters of glycolipid and glycosylphosphatidylinositol-anchored proteins in lymphoid cells: accumulation of actin regulated by local tyrosine phosphorylation. Eur J Immunol 1999;29:556-562. 


\section{Cellular Physiology Cell Physiol Biochem 2018;51:375-392}

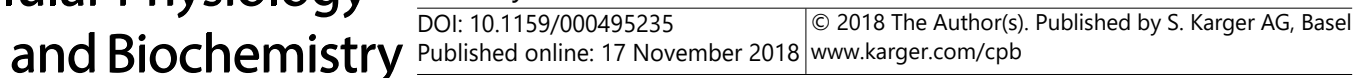

70 Brown DA, London E: Structure and function of sphingolipid- and cholesterol-rich membrane rafts. J Biol Chem 2000;275:17221-17224.

71 Brown DA: Lipid rafts, detergent-resistant membranes, and raft targeting signals. Physiology (Bethesda) 2006;21:430-439.

72 Mak KM, Wen K, Ren Ch, Lieber ChS: Dilinoleoylphosphatidylcholine reproduces the antiapoptotic actions of polyenylphosphatidylcholine against ethanol-induced hepatocyte apoptosis. Alcohol Clin Exp Res 2003;27:997-1005.

73 Davis BK: Inhibition of fertilizing capacity in mammalian spermatozoa by natural and synthetic vesicles; in J.J. Kabara (eds): Symposium of the Pharmacological Effect of Lipids. Amer. Oil Chem Soc, Champaign, IL, 1978, pp 145-157.

74 Cross NL: Role of cholesterol in sperm capacitation. Biol. Reprod 1998;59:7-11. 